\title{
DISPLACED VALUES: FROM REMEMBRANCE TO RESILIENCE
}

\author{
Geert Franzenburg \\ University of Muenster, Germany \\ Email: franzenburg@t-online.de
}

\begin{abstract}
The different considerations of this study analyze in biblical tradition and modern times experiences of displacement and their consequences for educational purposes and resilience. Exemplified by Baltic experiences, it demonstrates how memory constructs coping strategies, which can be transferred into models of enculturation and value-education. Following the stages of the Biblical story of Jewish exile and diaspora, the considerations analyze, how modern people in situations of crisis, transition, mobbing or displacement can draw benefit from the existential experiences memorized in these narratives and actualized in rituals as a memory-culture and process of enculturation. In this context, different memory cultures, focused on a common situation, underline different expressions of remembrance and suggest different approaches to cope with them: symbolic, ritualized, narrative. In this study the Exile-and Diaspora-oriented EXODUS, exemplified by the Baltic exile before and after 1945, facilitates a framework for educators to identify and integrate experiences of exile and diaspora into a concept of enculturation, which combines holistic exercises in non-violent communication, awareness, creative work, intercultural discourse and similar experiences. Furthermore, it assists them to facilitate opportunities to make helpful experiences in their own diaspora-like framework.
\end{abstract}

Key words: Baltic, diaspora, enculturation, Exodus, resilience.

\section{Introduction}

Why should people remember biblical narrations in a secular society? Why remember "ancient" postwar experiences of displacement in a generation, which characteristics are individualism and cosmopolitanism? Why doing this within a society, where people have to travel, caused by economic needs, to assimilate anywhere in the world?

The answer to such questions has to do with cultural identity as a dynamic process. It has to do with the sense of belonging, the sense of coherence and other coping and resiliencestrategies (Antonowsky, 1979): In order to recognize, where I belong, I have to become aware, from where I am coming. With such biographical and historical details in mind, people are prepared for future experiences of mobbing, transitions and disappointments.

Within the biblical and patristic model of Exodus as enculturation, this process of forming one's own cultural identity means to balance between exclusion and assimilation by integration; it also means building up one's own virtual home by balancing between remembrance and expectation. Following the narrations and rituals of different exile- and diaspora- communities in the Baltic context as value-systems, different coping strategies become obvious. These can be adopted for other resilience-oriented (educational) contexts and purposes, which influence attitudes.

Enculturation facilitates coping strategies not only in real exile and diaspora but also in their virtual form within contrary value systems. These strategies demonstrate that enculturation has to do with the transfer of one value system into another; it combines aspects of confession, as the integration of argument and emotion, with the process-oriented approach: Starting with a "contract" it recognizes traditions, narrations, rituals and rules within the framework of 
PROBLEMS

OF EDUCATION

IN THE $21^{\text {st }}$ CENTURY Volume 56, 2013

60

civic education. Therefore, the interplay between cultural and historical contexts and subjective experiences is crucial because it decodes the collective categories of homeland and heritage, and the different interpretations of "place and community within different diasporas, borderlands, exiles, detours, and returns” (Clifford, 1997, 34-35).

In the present study, the term 'diaspora' stands for " a relational network, characteristically produced by forced dispersal and reluctant scattering” (Gilroy, 1993, 318). In this network, war, famine, enslavement, ethnic cleansing, conquest and political repression, are a dominant influence and produce experiences of displacement. Because of the dispersal and alienation in the host country, the diaspora situation develops myths/memories of the homeland and the desire for eventual return. Therefore, diaspora means "expatriate minority communities (l) that are dispersed from an original center" to at least two "peripheral" places; (2) that maintain a memory vision, or myth about their original homeland"; (3) that believe they are not-and perhaps cannot be-fully accepted by their host country hat see the ancestral home as a place of eventual return, when the time' is right; (5) that are committed to the maintenance or restoration of this homeland, and (6) whose consciousness and solidarity as a group are importantly defined by this continuing relationship with their homeland (Safran, 1991, 83-84). These memories can be called trans-historical, because they allow to share one's own cultural identity with others by symbolic citizenship, by myths of belonging, by identifying with the 'starting-points' of other national and international histories and geographies (Bhabha, 1994, $\mathrm{XX}$ ). Therefore, the biblical tradition can be taken as a starting point for a discourse, which can be transformed into other frameworks.

\section{Background}

Because the connection between individuals and their homeland changes during decades, encoding this connection in symbols and narratives into a collective memory becomes an essential task (Assmann, 1995, 126). Connected to their myth and politics of homeland, members of segmented Diasporas differ concerning the actual contexts. Therefore, their members' identities, "are not fixed but situational determined" (Werbner, 2004, 900). Especially concerning values and beliefs, such segmentation and encoding of memories and emotions make it useful to find a key for decoding them. Although, social constructionist critiques, influenced by postmodernist readings, tried to decompose and to reorder the Diaspora-terms 'homeland' and 'ethnic or religious community', during the last decade a consolidation set in with a partial accommodation and consolidation, "marked by a modified reaffirmation of the Diaspora-idea" and its core elements (Cohen, 2008, 1-2). Nevertheless, decoding still is a challenge for research, because "diaspora "is in danger of becoming a promiscuously capacious category" (Tölölyan, 1996, 8) and home is seen as an "emotionally fraught terrain" (Moorti, 2003, 359), whose "mythical bond rooted in a lost past, a past that has already disintegrated” (Morley and Robins, 1996, 459). Therefore, the model of enculturation with its orientation on homeland, dispersion and boundary maintenance (Brubaker, 2005, 5-6) is a helpful concept in a society, which is coping with the experience of displacement and transition (Morley and Robins, 1996, 474).

\section{Focus}

One key of decoding memories and emotions concerning experiences of Exile and Diaspora is the Model of Exodus, which demonstrates strategies of remembrance, enculturation and coping.

It suggests integrating past, presence and future by remembrance, consideration and conceptualization. It also depends on the comparison and evaluation of different value-systems in order to create new attitudes, which belong to a situation.

This research intends such decoding by examples of enculturation, which transfer experiences of biblical or historical exile and diaspora into the environment and value-framework 
of modern students and pupils to help those developing resilience-skills. From the different categories of diaspora-members - "expatriates, expellees, political refugees, alien residents, immigrants and ethnic and racial minorities" (Safran 1991, 83) - the example of Baltic displaced Persons is chosen, because of their impressive and expressive historical experiences, collective narratives and differing relationships to homelands and exiles.

\section{The Concept of Exodus as Enculturation}

\section{General Remarks on the Concept}

The study puts stress on the key-concept of Exodus as enculturation during the educational process of awareness and communication. Regarding its elements, it has to do with different experiences of Exile and diaspora, exemplified by the Baltic experiences:

- The experience of belonging to a minority within a contrary majority and society (Egypt model),

- the experience of displacement and longing for the lost home (desert-model), and

- the experiences of exile and diaspora (Babylon-model).

- the experience of the global balance between cultural identity and assimilation.

In all these experiences, the concept of Exodus as enculturation becomes obvious and underlines its value for resilience-training through remembrance-culture, which is characterized by the difference between individual memory' and collective commemoration, and between national and transnational memories (Hackmann 2008). Furthermore, these experiences illustrate the remarkable 'in-between' spaces of diaspora and suggest "elaborating strategies of selfhood"..." in the act of defining the idea of society itself." (Bhabha, 1994, 1f.) - Private and public, past and present, psyche and social share their link in this "in between temporality" (Bhabha, 1994, 19), which also can be characterized as Transnationalism, as the process that transcend international borders and, therefore, is focused on the social elements of diaspora. (Faist, 2010, 13) The study follows the conviction that Diaspora as an "unbounded, analytical category" integrates a "perpetual recollecting identification with a fictitious or faraway existent geographic territory and its cultural-religious traditions (Baumann, 2000, 327-28). During this process of enculturation, cultural identity develops 'as a 'production' which is never complete, always in the process, and always constituted within, not outside, representation" (Hall, 1994, 392).

\section{Exodus as the Process of Enculturation}

The stages:

1. "But the more they afflicted them, the more they multiplied and grew". (Ex.1.12 KJB)

According to Hebrew tradition, a famine caused the migration to Egypt of the band of 12 Hebrew families that later made up a tribal league in the land of Israel with the help of JAHWE, who showed his faithfulness and power by liberating the Israelites from bondage and punishing their oppressors and regulating their conduct toward him and each other with his covenant. Therefore, Exodus as enculturation begins with the double experience of suffering and coping.

This is the experience of the Israelite servants in Egypt and also - mutatis mutandis - of the Baltic peasants, who suffer under their German master and, furthermore, several times occupied by foreign states (Sweden, Poland, and Russia). Especially living under German leadership was a crucial challenge. Like the little child Moses, they had to decide whether they become new nationals or keep on dependent and oppressed but with their own cultural identity. Such identity has to do with the differences between mother-tongue and foreign language and 
PROBLEMS

OF EDUCATION

IN THE $21^{\text {st }}$ CENTURY

Volume 56, 2013

62

the cultural or spiritual meaning of place and time and narratives: Until recent times, the own language became for the exiled Latvians and Estonians - like many other nations - the center of their cultural identity since the early days of indigenous history. Similar the date of the short national independence (November 18, 1918 (until 1940) and the homeland-landscape and soil became almost religious terms. Similar the German Balts - especially during the autocratic years 1934-39 show interest in using their own mother tongue and fought for this right of cultural autonomy. All Baltic inhabitants share common narratives about the value of language, rituals and homeland, but they use different pronunciations and subtexts. This reminds - as a resilience-skill and coping strategy - on enculturation as awareness of language and non-verbal messages and awareness of structures and rules and their overcoming. In educational contexts, young people can learn "from those who have suffered the sentence of history-subjugation, domination, Diaspora, displacement - enduring lessons for living and thinking" (Bhabha, 1994, 172) by exercising non-violent communication, by learning the difference between perception and interpretation, and by developing common rules.

2. Would to God we had died by the hand of the LORD in the land of Egypt, when we sat by the flesh pots, and when we did eat bread to the full; for ye have brought us forth into this wilderness, to kill this whole assembly with hunger. (Ex.16.3 KJB)

The liberation from Egypt laid upon Israel the obligation of exclusive loyalty to JAHWE. This meant eschewing all other god and idols and the elimination of all magical recourses. It also had to do with social solidarity, protected in the rules, and with a good-bye to the Egyptian home.

All these challenges, as the narrative of the golden calf underlines, were temptations for the people, which many could not resist. Therefore, Exodus as enculturation has to do with resilience through desert-journey while longing for a lost home.

The "desert-journey" of the displaced persons (DPs) from Latvia and Estonia started, when they arrived in Germany. In the DP-camps, they became objects of treatment by Allied forces, UNRRA personnel and German officials and administration. Their answer was to build up their "Little Latvia" or "Little Estonia" for never forget the lost homeland and to find a holistic approach for remembrance like the people of Israel in the desert with Manna and Water. In the DP-camps, the fundamental challenges were care and maintenance, but also spiritual care. Therefore, they answered the confrontation with external rules with escapingstrategies by dreams and common activities. In the context of the biblical Exodus-model, the observance of the Sabbath reminds on the value of sacred times/moments as memory culture, and the fundamental change between attention and relaxation. Also, the person of Moses represents a situation between past and future home, and also as a symbol for the transition from community to Diaspora-oriented nation (Gilroy, 1997, 302). Similar to Moses also in modern exile-experiences, guidance - e.g. by soul-care experts or organizations - is helpful: it facilitates opportunities for transition by choosing the right contents, times and places. Concerning such experiences, the question of belonging and the relationship between structure and discourse facilitates resilience-skills and coping-strategies by reminding on the value of an open-minded attitude towards miracles (Manna, water), contracts and rules (Ten Commandments), and sacred places (tabernacle). The renewing of the covenant after the temptation of the golden calf reminds on the value of a second chance, of forgiveness, and grace. It assists people in coping with faults, disappointments and facilitates resilience. Therefore, in educational contexts, it might be helpful to facilitate guided desert-experiences or pilgrimage, in order to become aware of the chances, challenges and temptations of being a migrant (Durham-Peters, 1999, 18). This could be in common weekends and holistic experience-oriented outdoor-eduation.

3. Seek the peace of the city whither I have caused you to be carried away captives, and pray unto the LORD for it: for in the peace thereof shall we have peace. (Jer.29,KJB) 
Exodus as enculturation means coping with exile-experience in foreign countries missing one's own country. The DPs in their image of the home country and its people depend on nation-state caused nationalism, from which springs stereotype of Lithuanianess, Estonianess, Latvianess as an inborn and inscribed phenomenon. Their image of home country depended on the typical political refuge experience. Occupied and suffering, they nevertheless succeed - during a long way - in regaining nation and retaining its culture (Ciubrinskas 2004, 49). For the Baltic tradition, the issues of history and the collective memory of victimhood have been of paramount domestic importance in determining how to deal with diaspora experiences (Cheskin, 2012, 566). Therefore, the experience of Exile and Diaspora form a "mnemonic community" by synchronized memories (Zerubavel, 2003, 4): In the model of Exodus, guidance and also teaching in this way become a process of initiation and the guide/teacher acts as a mystagogue towards such a commemorating community. Like Moses' encounter with the God of Abraham, Isaac and Jacob integrated his life-experiences into a broader framework, also the prophet Jeremiah in his message to the exiled people underlines the value of traditions. Like the miraculous crossing of the Red Sea, live at the rivers of Babylon and coping with foreign cultures and cults illustrate the meaning of translation and transition and the value of symbols and rituals during this process. Also, young people make the experience of stages of transition in life and have to cope with translations of messages from an unknown into their mother-tongue (and vice versa). Therefore, in educational contexts, creative work with symbols or rituals for separation- or transition-experiences and intercultural dialogue are helpful methods.

\section{4. "The twelve tribes scattered abroad" (John 1:1 KJV)}

Although Jews often allude to their earlier period as slaves in ancient Egypt, particularly in the Passover rituals that recount the story of the Exodus, it was the destruction of Solomon's laboriously-constructed temple in $586 \mathrm{BC}$ by the Mesopotamian Empire that characterizes the central folk memory of trauma. Jews had been compelled to desert the land 'promised' to them by God to Moses and thereafter, the tradition suggests, forever became dispersed. Therefore, Exodus as enculturation confronts people with the challenge to cope with Diaspora and displacement, although there is one's own country and a faraway homeland. Also in the Baltic tradition Diaspora develops into a global framework, in which the global community and communication have to be exercised by avoiding stereotypes and sharing diaconal and spiritual aid. As a myth or collective memory of their homeland, they regard it as their true home, to which they will eventually return to restore or maintenance it. They relate to the homeland as to a point, where it shapes their identity, by symbols, heroes, rituals and values during the process of enculturation (Hofstede, 1997).

In the case of the Baltic diaspora, the starting point of such collective memory (Halbwachs, 1992) was forced displacement that in their folk memories restore the (virtual) homeland; the returning there became - like in other cases -an "important focus for social mobilization, and the mold in which their popular cultures and political attitudes are formed" (Cohen, 2008, 4). The Baltic DPs show the Diaspora-characteristics: to be dispersed from an original center, to share a collective memory, to be not fully accepted in the host societies, idealize the ancestral home, hope to return; task of restoration of the original homeland (Cohen 2008, 6). Therefore, Exodus as enculturation reminds on the value of biographical work (search for one's roots and sharing of memories) and to avoid the focus on ethnicity (Floya, 1998, 558). In educational contexts, discussion and discourse about home, values, dreams and visions can open for new experiences. 


\section{PROBLEMS \\ OF EDUCATION \\ IN THE $21^{\text {st }}$ CENTURY Volume 56, 2013 \\ 64 \\ Summary}

How can the EXODUS model help to decode encoded experiences of exile and diaspora?

The short overview concerning crucial aspects of the Jewish and Baltic Exile- and Diaspora- narrations demonstrates how a community develops into a virtual nation with a religious self-consciousness. By building up an inner refuge, by recognizing the value of language, narrations and rituals, of memorable places and times, of dreams and internal rules for memory cultures, such holistic process of enculturation facilitates opportunities for learning how to encounter and share experiences as a community of remembrance and expectation. Although modern people mostly do not feel suffering like Israel, they nevertheless, got experiences of inner exile and diaspora situations, when they remember the lost paradise or long for a better reality. Learning from the biblical and historical experiences of coping with displacement, they gain strategies for resilience, according to their own crisis- and "displacement"- situations.

Cultural identity as a living process of "positioning" (Hall 1993) depends on memory, fantasy, narrative and myth. Latvian and Estonian Migrants got the power to cope with experiences of minority-existence, exile and diaspora by focusing on their mother tongue and motherland, illustrated by songs, symbols sermons and narratives. Therefore, the religious impact of displacement and life in exile communities suggests further studies based on these results. They confront with the challenge of coping with stereotypes, cultural identity, assimilation and political intentions and with the chance to find one's own way of enculturation in foreign circumstances.

Further research should be done, whether other models of diaspora - Jewish Zionism, Armenians, African and American colonialism - confirm these results. Another point of discussion is the challenge of "translation" and of transferring this balance and ambivalence of displacement and belonging into the often virtual reality of young Europeans in the 21 Century. Therefore, value-education as an approach to provide young students with a spiritual home, facilitates opportunies for nonviolent intercultural communication and for developing one's own memory-culture in schools and other institutions.

\section{Conclusions}

The results underline that enculturation by remembrance can become a coping strategy in experiences of exile and diaspora of any kind and a starting point of a new process of enculturation by demonstrating: I only know, where I belong, when I learn, from where I am coming.. Although separated from the situation and the background of the biblical events and from the Exile-years after 1945, young students of today share analogue experiences of minority status, of oppression, suffering, coping and need resilience-skills. Learning from far external experiences, they become aware of the challenge to see adoption as a lost home, and to build up the ambivalent and hybrid cultural identity of Diaspora. They can use confessions as an expression of collective memory, narrations and attitudes, and make the experience with enculturation as the process of group-consciousness. They can understand translation and tradition as a way to form relationships with the ancestral home, and to share narrations and rituals as forms of responsibility for each other. Learning from the experiences of the Jews in Egypt and the desert, they can start a long-term holistic and guided process, which integrates the awareness of language, messages and sub-texts, of sacred times and places and past, presence and future in each single biography. Therefore, they gain strategies, which help them to overcome crises and conflicts and to resist against temptations.

Therefore, following the concept of Exodus as enculturation means to assist young students in schools, universities and other institutions to find and share new points of view towards their life-experiences. 


\section{References}

Antonovsky, A. (1979). Health, Stress and Coping. San Francisco: Jossey-Bass Publishers.

Assmann, J. (1995). "Collective Memory and Cultural Identity.” New German Critique, 65, 125-33.

Baumann, M. (2000). 'Diaspora: genealogies of semantics and transcultural comparison', Numen, 47 (3), 313-337.

Bhabha, H. K. (1994). The location of culture. New York: Routledge.

Brubaker, R. (2005). Diaspora< Diaspora. Ethnic and Racial Studies, 28, (10, 1-19.

Bruneau, M. (2010). Diasporas, transnational spaces and communities. Diaspora and Transnationalism: Concepts, Theories and Methods, edited by Rainer Bauböck and Thomas Faist. Amsterdam: University of Amsterdam, 35-49.

Cheskin, A. (2012). History, conflicting collective memories, and national identities: how Latvia's Russian-speakers are learning to remember. Nationalities Papers, 40 (4), 561-84.

Ciubrinskas, V. (2004). Transnational Lithuanian identity: imagined, constructed and contested in diaspora. Kockel, U., Nic Craith, M. (Eds.) Communicating Cultures. Muenster: LIT Verlag. 42-66. Clifford, J. (1994). Diasporas. Cultural Anthropology, 9, (3), 302-338.

Clifford, J. (1997). Routes: Travel and translation in the late twentieth century. Cambridge, MA: Harvard University Press.

Cohen, R. (2008). Global Diasporas: An introduction. New York: Routledge.

Durham Peters, J. (1999). Exile, nomadism, and diaspora: the stakes of mobility in the western canon. Naficy, Hamid (ed.), Film, media, and the politics of place. New York: Routledge, 17-44.

Faist, T. (2010). Diaspora and transnationalism: What kind of dance partners? Diaspora and Transnationalism: Concepts, Theories and Methods (ed. by Rainer Bauböck and Thomas Faist) Amsterdam: University of Amsterdam, 9-34.

Floya, A. (1998). “Evaluating 'Diaspora': Beyond Ethnicity?” Sociology, 32, (2), 557-580.

Gilroy, P. (1993). The Black Atlantic: Modernity and double consciousness. Cambridge, MA: Harvard University Press.

Gilroy, P. (1997). Diaspora ad the detours of identity. Woodward, Kathryn (Ed.), Identity and difference, Milton Kaynes: Open University, 299-346.

Hackmann, J. (2008). Collective Memories in the Baltic Sea Region and Beyond: National - Transnational - European? Journal of Baltic Studies, 39, (4), 381-391. Halbwachs, M. (1992). On collective memory, Chicago: The University of Chicago Press.

Hall, S. (1994). "Cultural Identity and Diaspora." Colonial Discourse and Post-colonial Theory: A Reader (Ed. By Patrick Williams and Chrisman), London: Harvester Wheatsheaf, 392-401.

Hofstede, G., Hofstede, Gert J., Minkow, M. (1997). Cultures and Organisations: Software of the Mind (2nd edn). New York: McGraw Hill.

Moorti, S. (2003). Desperately Seeking an Identity: Diasporic Cinema and the Articulation of Transnational Kinship. International Journal of Cultural Studies, 6 (3), 355-376.

Morley D., Robins, K. (1996). No Place Like Heimat: Images of Home (land) in European Culture". G. Eley and R. G. Suny (Eds), Becoming National, Oxford; New York: Oxford University Press.

Safran, W. (1991). Diasporas in Modern Societies: Myths of Homeland and Return. Diaspora, 1 (1), 8399.

Tölölyan, K. (1996). Rethinking diaspora (s): Stateless power in the trans-national moment. Diaspora, $5(1), 3-36$

Werbner, P. (2004). Theorising complex diasporas: Purity and hybridity in the South Asian public sphere in Britain. Journal of Ethnic and Migration Studies, 30 (5), 896-911.

Zerubavel, E. (2003). Time maps: Collective memory and the social shape of the past. Chicago: University of Chicago Press.

Advised by Laima Railiene, University of Siauliai, Lithuania

Received: September 28, 2013

Accepted: November 11, 2013

Geert Franzenburg
Lecturer, University of Muenster, Eichenaue 5, D-48157, Muenster,

Germany.

E-mail: franzenburg@t-online.de 